\title{
ON THE GLACIAL ORIGIN OF HURONIAN ROCKS OF NIPISSING, ONTARIO
}

\author{
REGINALD E. HORE \\ Michigan College of Mines, Houghton, Mich.
}

In the early (I846 ff.) reports of the Canadian Geological Survey there appear descriptions by Sir William Logan of a series of nonfossiliferous clastic rocks found on the west shore of Lake Temiskaming and north of Lake Huron. Logan correlated the rocks of the two localities and gave them the name Huronian. He believed them to be younger than and made up partly of detritus from the Laurentian, and his conclusions have been verified by later observers.

Recently these rocks have attracted more than local interest on account of the discovery of rich silver veins at Cobalt. As a result of their economic importance the rocks have been subjected to much closer examination than before and many interesting features have been noted. Among these are peculiar characters which are strongly suggestive of the existence of glaciers in Nipissing in early Huronian times. Dr. A. P. Coleman ${ }^{1}$ who has made a study of these rocks from the standpoint of the glacialist, has gathered evidence from which he concludes that there is no doubt of the glacial origin of the basal conglomerate of the lower Huronian. It is purposed here to present some facts which bear on this question.

The chief rocks in this district are of the Archean and Algonkian groups. These are separated by a very marked unconformity and the interval was doubtless the greatest which occurred in the preCambrian times. There is no good reason to doubt that for a long period of time the Archean rocks were being worn down by all or any of the erosive agents now active.

The Huronian series doubtless represent a portion of the secondary rocks thus formed, and they are entirely composed of detrital material. They are conveniently grouped into an upper and a lower series,

x “The Lower Huronian Ice Age," Jour. Geol., XVI (I908), I49-58. 
which are generally conformable but in some localities separated by a slight unconformity.

The upper series is made up largely of medium-grained feldspathic quartzite with a little conglomeratic material. It presents no unusual feature and doubtless represents the hardened accumulation of a feldspathic sand derived from siliceous holocrystalline igneous rocks of the Laurentian group.

The lower series is made up largely of conglomerate, shale, graywacke, and feldspathic quartzite. In many cases there is gradual

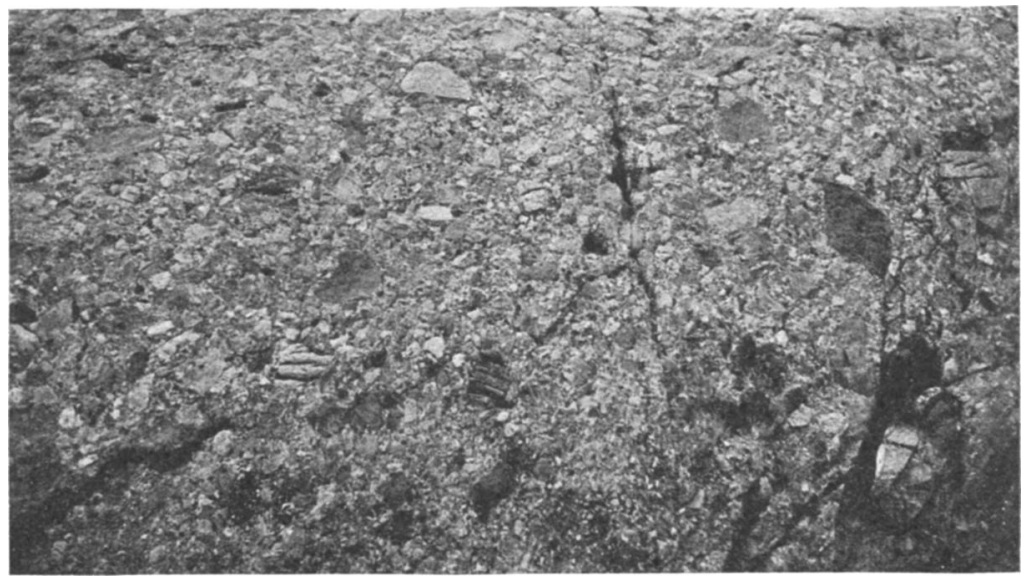

FIG. I.-Huronian conglomerate near Temagami, Ont.

gradation vertically from one of these types to another. Less often there is a sharp division line. The composition of one stratum is often fairly constant for some distance; but in some cases a distinct change takes place in a few feet laterally as well as vertically.

The shales are for the most part of gray color, less often greenish black. Occasionally they are interbanded with layers of purple, green, and pale-gray colors. The chief recognizable minerals are quartz and altered feldspars, minute scales of chlorite and sericite, and small grains of epidote, titanite, and iron ores. In mineralogical and chemical composition they are not unlike green shales of other formations.

The quartzites are in most instances feldspathic and grade insen- 
sibly into typical arkoses. They are usually very massive, fine to medium grained, and not unlike light-colored granite in appearance. It is often very difficult to determine their structure as there are seldom well-marked bedding planes. There are however instances in which the bedding is indicated by variations in the size and relative proportions of the various grains and other cases in which it is indicated by horizontal jointing. The rock is very largely composed of quartz and feldspar. Sericite and kaolin are prominent in lightcolored varieties and chlorite in the darker. Titanite and iron

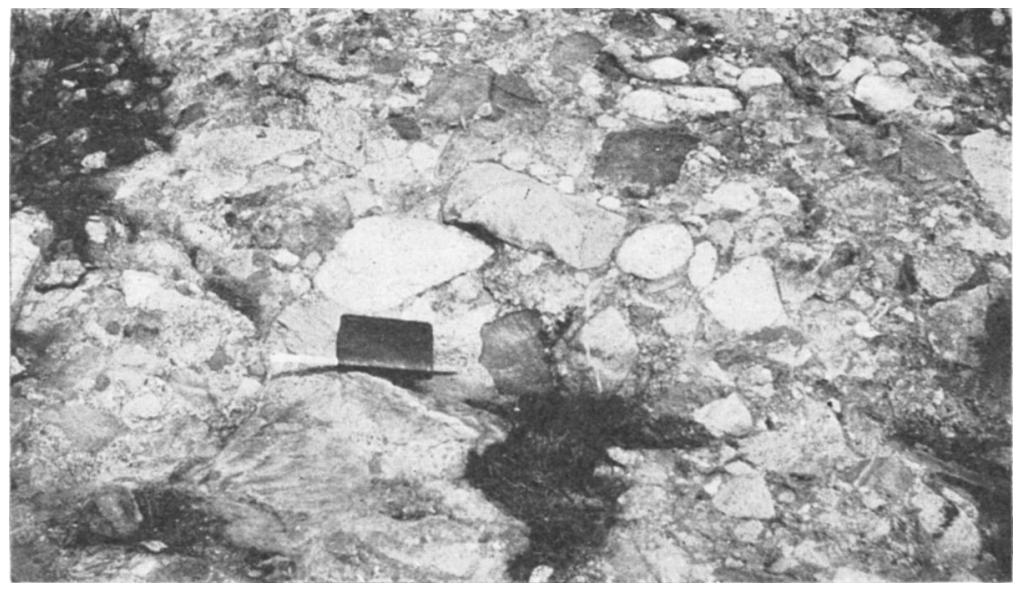

FIG. 2.- Huronian conglomerate, Temagami, Ont. Steel scale (in book) is one foot long.

ores are usually present in small quantity. The feldspar and quartz grains are often well rounded but quite as frequently angular or subangular.

Closely allied to the shales and arkoses are the graywackes. The chief recognizable constituents in these are feldspar, quartz, a dark chlorite, and a pale-colored mica. Less abundant are small particles of iron ore and epidote, while pyroxene and amphibole are rare. With the minerals are angular and rounded rock particles of various sizes. Rock of this type in some instances is found in massive beds of uniform character, very fine grained and of gray to greenish color. Similar material forms the matrix of much of the bowlder conglomerate. 


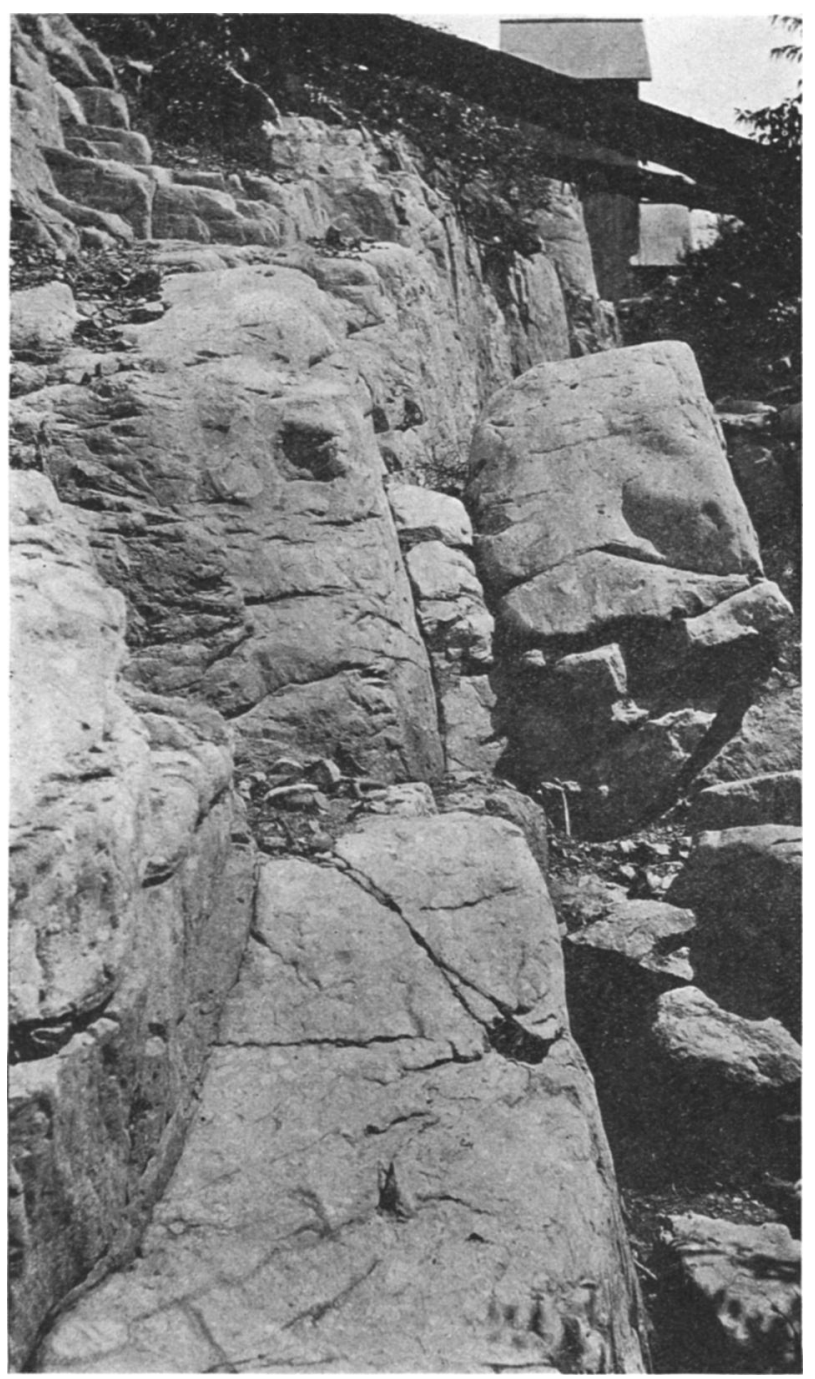

Fig. 3.- Huronian conglomerate, Buffalo Mine, Cobalt, Ont. A common type, little evidence of stratification.

This content downloaded from 128.143.023.241 on August 12, 2016 04:02:07 AM All use subject to University of Chicago Press Terms and Conditions (http://www.journals.uchicago.edu/t-and-c). 
The conglomerate is remarkable for its heterogeneous appearance. Not only are the bowlders of a great variety of types but in many cases they show no evidence of arrangement according to size. Frequently one finds bowlders a foot in diameter scattered irregularly and sparsely through an aphanitic matrix of shale or graywacke, thus simulating glacial deposits. In other cases there are thick beds of shale quite free from such erratics. There are also beds of bowlders of nearly equal size packed close together and with but little of fine-grained matrix,

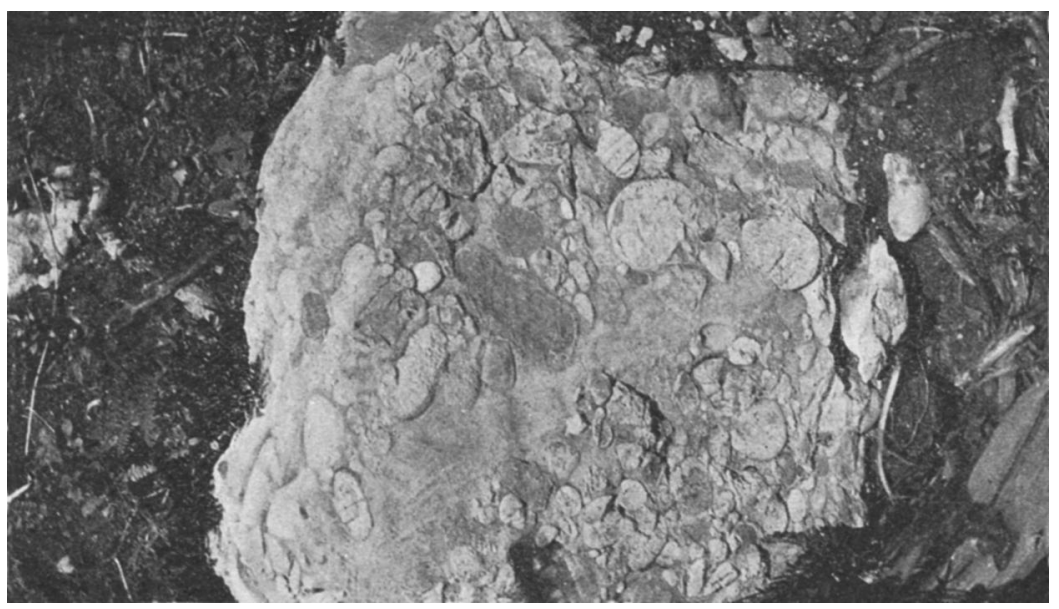

FIG. 4.-Huronian conglomerate, Buffalo Mine, Cobalt, Ont. A weathered surface of coarse facies.

as in an ordinary water accumulation of coarse gravel. In some instances the aphanitic beds are distinctly laminated as in ordinary water-laid clay, while again similar material forms a compact rock lacking in well-developed bedding planes.

As a general rule the large bowlders are well rounded or subangular; but there are occasional streaks containing markedly angular fragments. Dr. Coleman found some bowlders at Cobalt which show striae and concaved surfaces.

The matrix of the conglomerate, which is often graywacke and less often shale, contains numerous angular particles of quartz, feldspar, chert, and felsites. Particles of such shape are very characteristic of, though they are by no means found only in, glacial débris. 
Where the contact of the conglomerate with underlying rocks has been found there is a noteworthy lack of alteration in the older rocks. If they were deeply disintegrated by surface weathering the material must have been removed by a very efficient agent. This again suggests ice action. In a few of the contacts the line of demarcation is less distinct, as is ordinarily the case with unconformities in waterlaid sediments. Naturally the contacts of the latter type are not so likely to be found as those of the former.

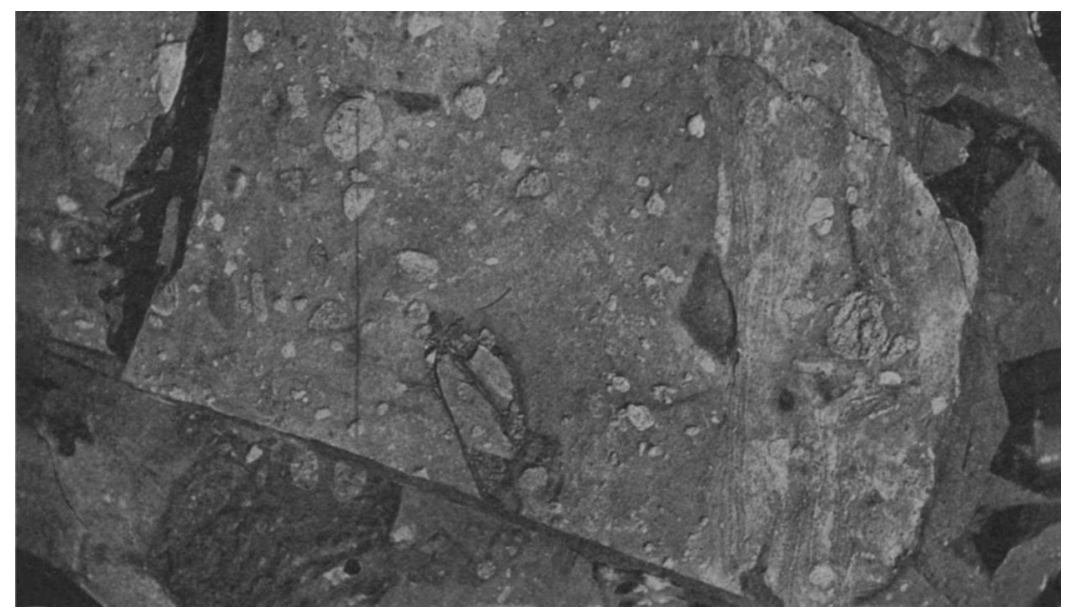

FIG. 5.-Huronian conglomerate, Coniagas Mine, Cobalt, Ont. A horizontal exposure.

There has not yet been found a smooth or striated floor. The basal conglomerate, in some cases at least, has been formed in situ and is made up of detritus from the immediately adjacent rocks.

Professor Coleman does not consider that the lack of discovery of a characteristic glacial floor precludes the possibility of the material having been placed by ice, and refers to well-known instances in which such a floor is lacking.

The localities specially mentioned by Dr. Coleman are Cobalt and Temagami. Cobalt Lake, on which the town is situated, lies almost entirely in Huronian conglomerate. The conglomerate in turn lies in a deeper valley formed by rocks of the Keewatin group. It might be expected therefore that the coarser material in the conglomerates 
would be largely detritus from these old greenstones and cherts; but such is by no means the case. The basal portion is made up

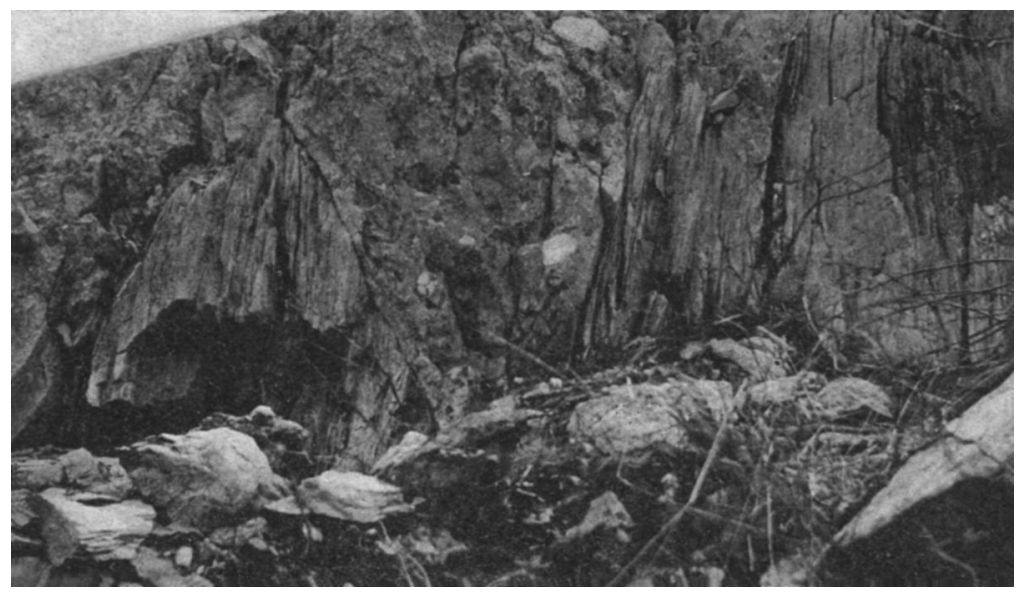

FIg. 6.-Huronian conglomerate on Keewatin slate. Near Temagami Ont.

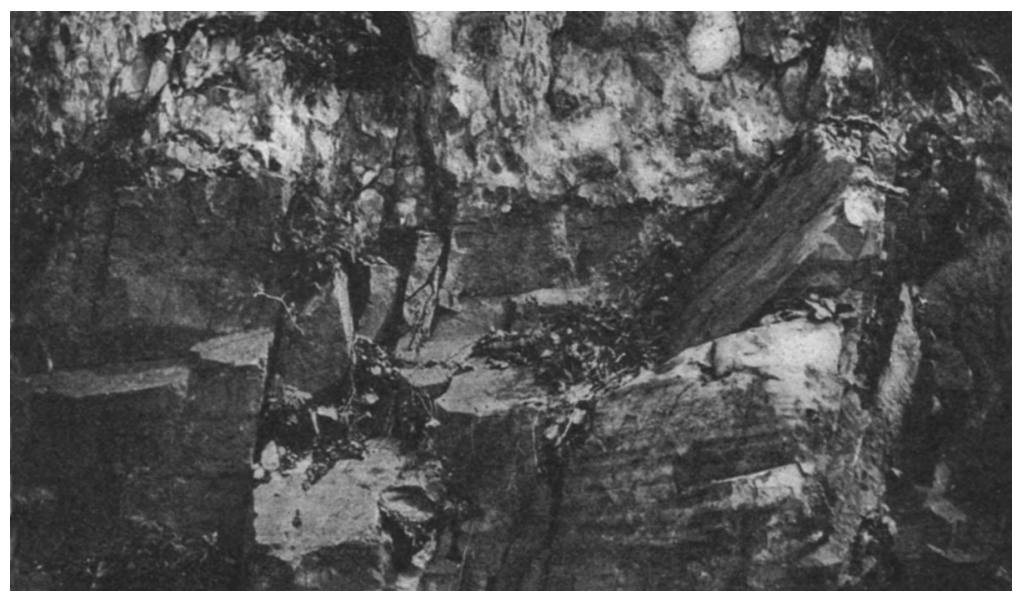

FIG. 7.-Coarse conglomerate on greywacke (Huronian). Temagami, Ont.

very largely of material similar to that which inclosed the old valley; but the greater portion of both bowlders and matrix is quite different. There are not now exposed any near-by hills from which these mate- 
rials might have been brought down, nor is there good reason to believe that such hills existed in Huronian times. The nearest outcrops of Laurentian rocks from which many of the bowlders may have been derived are some miles distant. Many of the large bowlders are quite unlike any rocks which have been found in place in the district. Evidently ice was the most competent agent to bring such materials to their present position, and to deposit them in such a heterogeneous manner.

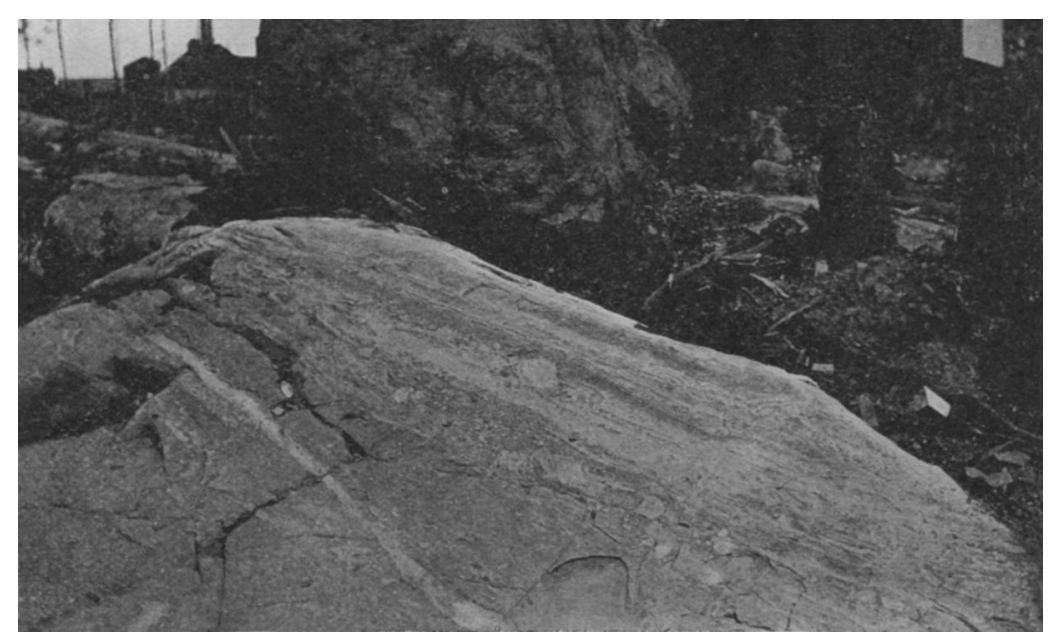

FIG. 8.-Huronian conglomerate, Trethewey Mine, Cobalt, Ont. Shows stratified and unstratified portions. Such well-banded portions are of quite small extent as compared with the unstratified. One of the streaks contains distinctly angular fragments.

At Temagami the conglomerate lies on Keewatin schists and at its base contains numerous fragments of them. The conglomerate also contains numerous rounded and subangular bowlders of rocks not found close by. The underlying rock presents a fairly fresh but not a smooth surface. The matrix of the basal conglomerate contains numerous well-formed rhombohedra of siderite, and similar crystals are abundant in shale and quartzite beds in the conglomerate. They were evidently derived by weathering from the adjacent iron formation and the crystals were growing freely contemporaneous with the mechanical deposition of clay, sand, and bowlders. It is probable 
therefore that the conglomerate was formed under water and that there was carbonate in solution. If the larger erratics were brought by ice it was probably not land ice.

\section{SUMMARY}

In appearance the conglomerate-quartzite-shale series of the Huronian represents nothing so closely as compacted glacial and glacio-fluvial débris. The finding of striated and soled pebbles confirms the supposition of such an origin. The character of the contacts thus far found do not disprove that glaciers placed the basal conglomerate, though they suggest that such was not the case.

There are some sudden transitions from shale to coarse conglomerate which suggest that the earlier deposits may have been overridden by land ice. It seems probable however that part of the material was deposited under water and that floating ice contributed its load of glacier-derived material.

There is no reason for supposing that the thick bowlder-free beds of shale and graywacke are not ordinary water-laid sediments, though they may contain glacial floor. 